\title{
New Insights into Relational Goods
}

During the last thirty years, the value of the human relational and communicative dimension has been emphasised in numerous studies, first, because of its part in creating meaning and in the development and sustainability of diverse spheres of human activity, including economic activity; and second, because of its role in different processes of social change. This new personal and reciprocal paradigm offers a perspective from which to observe, analyse, describe and understand social reality beyond simple self-interested individual actions and merely welfare-based structural effects that undervalue the transformative potential of the reality of civil society and spawn individualistic, dependent, disaffected and dehumanised citizens.

\section{Nuevas perspectivas en el ámbito de los bienes relacionales}

PIERPAOLO DONATI Y PATRICI CALVO

UNIVERSTTÀ DI BOLOGNA Y UNIVERSTTAT JAUME I

Durante los últimos treinta años, diversos estudios han destacado el valor de la dimensión relacional y comunicativa del ser humano. Por una parte, por su implicación tanto en la creación de sentido como en el desarrollo y sostenibilidad de los distintos ámbitos de actividad humana, incluso el económico; y por otra parte, por el papel que juega en los diferentes procesos de cambio social. Un nuevo paradigma personal y recíproco desde el que observar, analizar, describir y comprender la realidad social más allá de acciones individuales autointeresadas y efectos estructurales meramente asistenciales que menosprecian el potencial transformador de la realidad de la so- 
Underlying this relational paradigm is the idea of a society in a continuous process of change, due largely to the reciprocal relationships that its citizens forge and maintain from their autonomy and social and moral commitment; that is, social reality mainly emerges as a result of those processes of associational activity generated and managed by the actors of civil society $^{1}$ themselves to meet different needs. From this point of view, "attempting to understand social change therefore means attempting to grasp the internal relationality of the social" (Donati, 1993: 48).

This growing concern for human relational value has led to the "discovery of other goods that lend substance to democracy in all its dimensions: social, cultural, economic and political" (Donati, 2013: 155), such as relational goods, one of civil society's most relevant and genuine mechanisms of cohesion and coordination for action.

The term relational goods was coined by philosopher Martha Nussbaum in The Fragility of Goodness: Luck and Ethics in Greek Tragedy and Philosophy (1986), but simultaneously studied and developed by, in the

1 Civil society is understood here as "all social spheres that can act autonomously in relation to the political and the economic systems" (Donati, 2000: 20).

ciedad civil y promueven una ciudadanía individualista, dependiente, desencarnada y deshumanizada.

Tras este paradigma relacional subyace la idea de una sociedad en continuo proceso de cambio gracias, sobre todo, a las relaciones recíprocas que forjan y mantienen sus ciudadanos desde la autonomía y el compromiso social y moral; es decir, la realidad social emerge principalmente como consecuencia de aquellos procesos de actividad asociativa generados y gestionados por los propios actores de la sociedad civil ${ }^{1}$ para satisfacer diferentes necesidades. Desde este punto de vista, «intentar comprender el cambio social significa entonces intentar captar la interna relacionalidad de lo social» (Donati, 1993: 48).

Esta emergente preocupación por el valor relacional del ser humano ha originado el «descubrimiento de otros bienes que dan sustancia a la democracia en todas sus dimensiones, social, cultural, económica y política» (Donati, 2013: 155), como, por ejemplo, los bienes relacionales, uno de los mecanismos de cohesión y coordinación de la acción genuinos y más relevantes de la sociedad civil..

1 Por sociedad civil se entiende aquí «todas las esferas sociales que pueden actuar de forma autónoma tanto con respecto al sistema político (Estado) como económico (Mercado)» (Donati, 2000: 20). 
main, sociologist Pierpaolo Donati, economist Benetto Gui and political scientist Carole J. Uhlaner ${ }^{2}$. In her reinterpretation of Aristotelian thought, Nussbaum referred to relational goods as those interpersonal and shared human experiences where the good is the relationship itself, not its results. She also suggested that the generation and strengthening of relational goods were implicit in satisfying the eudaimonic happiness of all those involved. For Nussbaum, friendship, trust, reciprocity, identity, love, democratic participation and civil commitment, to give some examples, are specific forms of goods that are born and die with the relationship and that enable stable interactions that are humanly enriching for all their participants.

This, however, was a reflection on a classical concept, and not a new theory of the relational goods emerging in the societies of advanced modernity.

2 Although somewhat later, other scholars are studying the implications of relational goods in their own fields of study. Of note are the economists Luigino Bruni and Stefano Zamagni and the psychologist Robert Sugden.

El término bienes relacionales fue acuñado por la filósofa Martha Nussbaum en The Fragility of Goodness: Luck and Ethics in Greek Tragedy and Philosophy (1986), pero estudiado y desarrollado al mismo tiempo por el sociólogo Pierpaolo Donati, el economista Benetto Gui y la politóloga Carole J. Uhlaner principalmente. ${ }^{2}$ En su reinterpretación del pensamiento aristotélico, Nussbaum tituló como bienes relacionales aquellas experiencias humanas interpersonales y compartidas donde el bien lo constituye la relación misma, no sus resultados. Además, sugirió que su generación y potenciación estaban implicadas en la satisfacción de la felicidad eudaimónica de todos los implicados. Para ella, la amistad, la confianza, la reciprocidad, la identidad, el amor, la participación democrática o el compromiso civil, por ejemplo, son formas específicas de bienes que nacen y mueren con la relación y que permiten el establecimiento de interacciones estables y humanamente enriquecedoras para todos los participantes.

2 Aunque su acercamiento al concepto fue posterior, existen otros pensadores realizando estudios sobre las implicaciones de los bienes relacionales en sus diferentes ámbitos de estudios. Destacan al respecto economistas como Luigino Bruni, Stefano Zamagni y Robert Sugden. 
Other studies on relational goods have identified certain basic characteristics that make them a particular type of social capital: a) they flow from symmetrical, free and responsible relationships; b) they cannot be instrumentalised; c) they grow with use and weaken with disuse; d) they allow participants to establish robust and stable associative actions capable of meeting needs and shared objectives; e) they are generated and enjoyed in company; f) they are intrinsically democratic; and g) they offer relational value, implicit in developing people's self-realization ${ }^{3}$. Therefore, among other things, this relational capital is perceived as a feasible possibility to offer responses to the new challenges of the twenty-first century. These challenges include the realisation of a mature society, distanced from the traditional State-market dichotomy - which fosters individualism and promotes citizen disaffection - that can participate and engage with everything it is affected by and responsible for. This is especially pertinent in an economic, social and moral crisis such as today's, where public managers and capitalist businesses - raised on the foundations

3 For more a in-depth analysis of relational goods, see Donati (2013: 155-177) and Donati and Solci (2011).

Pero esta fue una reflexión sobre un concepto clásico, y no era una nueva teoría de los bienes relacionales emergentes en la sociedad de la modernidad avanzada.

Otros estudios sobre los bienes relacionales han mostrado ciertas características básicas que los convierten en un tipo especial de capital social: a) fluyen de relaciones simétricas, libres y responsables; b) no pueden ser instrumentalizados; c) crecen con el uso y se empobrecen con el desuso; d) permiten a los participantes establecer acciones asociativas robustas y estables capaces de satisfacer necesidades y objetivos compartidos; e) se generan y disfrutan en compañía; f) mantienen un carácter intrínsecamente democrático; y g) ofrece valor relacional, implicado en el desarrollo de la autorrealización humana ${ }^{3}$.De ahí que, entre otras cosas, se perciba este capital relacional como posibilidad factible para ofrecer respuestas ante los nuevos desafíos del siglo xxi. Entre ellas, la concreción de una sociedad madura que, alejada de la tradicional dicotomía entre Estado y mercado, que fomenta el individualismo y promueve la desafección ciudadana, sea capaz de participar y comprometerse con todo aquello que le afecta y compete.

3 Para una mayor concreción de los bienes relacionales, Donati (2013: 155-177) y Donati y Solci (2011). 
of instrumental and disaffected rationality - have repeatedly shown their inability to satisfy, on their own, the legitimate needs and expectations of society.

However, the need remains to continue contributing to the creation of meaning and the development of relational goods, not only in the private and interpersonal sphere, but also in the public sphere. This is important, first, to clarify the concept in order to prevent, among other things, its repeated confusion with public goods; and second, to further explore its characteristics, roles, and possible mechanisms of application and implementation in order to enhance its suitability and realisation in different social spheres.

These questions are at the core of this special issue of Recerca. Revista de Pensament $i$ Anàlisi entitled "New Insights into Relational Goods". The main objective of this issue is to contribute new approaches and ideas that will improve understanding and enrich the theory. Through five proposals approached from different fields - sociology, politics, economics and law - its potential is revealed and new avenues described for its application and practical implementation.

Máxime ante una crisis económica, social y moral como la actual, donde gestores de lo público y empresas capitalistas -erigidas sobre los cimientos de una racionalidad instrumental y desencarnada- han mostrado en repetidas ocasiones su incapacidad para satisfacer por sí solas las necesidades y expectativas legítimas de la sociedad.

Sin embargo, persiste la necesidad de continuar contribuyendo a la creación de sentido y al desarrollo de los bienes relacionales, no solamente en la esfera privada e interpersonal, sino también en la esfera pública. Por un lado, clarificando el concepto para evitar, entre otras cosas, su reiterada confusión con los bienes públicos; y por otro lado, profundizando en sus características, roles, y posibles mecanismos de aplicación e implementación para potenciar su adecuación y concreción en las distintas esferas sociales.

Estas cuestiones referidas constituyen el eje transversal sobre el que se desarrolla este monográfico de Recerca. Revista de Pensament $i$ Anàlisi titulado «New Insights into Relational Goods». Así, el principal objetivo de este trabajo será, precisamente, aportar nuevos planteamientos e ideas que mejoren su comprensión en este sentido y enriquezcan la teoría. De esta forma, y a través de cinco propuestas diseñadas desde diferentes ámbitos, como la sociología, la política, la economía y derecho, será posible discernir su poten- 
In the first article, "Relational Goods and Their Subjects:The Ferment of a New Civil Society and Civil Democracy", Dr. Pierpaolo Donati reflects on how and in what way relational subjects and the goods they produce can contribute to develop a more robust and sustainable civil society. The author speaks about the conceptual framework of relational goods from the perspective of relational sociology, a proposal that moves away from methodological holism and individualism to address the phenomenon as a seed of "relational subjects"; that is, from the study and understanding of the relational dimension of the person. Donati then describes a relational social State that, built on values like subsidiarity and solidarity - the base for a mature society with associative capacity and competency, is nourished by relational subjects whose actions contribute to its development and sustainability through the creation and implementation of institutions capable of generating relational goods.

In the second article, entitled "Relational Goods and Resolving the Paradox of Political Participation" Dr. Carole J. Uhlaner proposes a plausible explanation for the disconcerting fact of civil society's democratic participation from the relational goods perspective; in other words, why supposedly selfish people are capable of participating in political processes

cialidad y dilucidar nuevos caminos para su aplicación e implementación práctica.

A lo largo del primer artículo, titulado «Relational Goods and Their Subjects:The Ferment of a New Civil Society and Civil Democracy», el Dr. Pierpaolo Donati reflexionará sobre en qué sentido y de qué forma los sujetos relacionales y los bienes que producen pueden contribuir a desarrollar una sociedad civil más robusta y sustentable.Así, el autor nos hablará del marco conceptual de los bienes relacionales desde la perspectiva de la sociología relacional, una propuesta que se aleja del holismo e individualismo metodológico para abordar el fenómeno como germen de los «sujetos relacionales»; es decir, desde el estudio y la comprensión de la dimensión relacional del ser humano. Posteriormente, Donati nos expondrá un Estado social relacional que, edificado sobre valores como la subsidiaridad y la solidaridad -base de una sociedad madura con capacidad y competencia asociativa-, se nutre de sujetos relacionales cuyas acciones contribuyen a su desarrollo y sostenibilidad a través de la creación e implementación de instituciones capaces de generar bienes relacionales.

En el segundo artículo, titulado «Relational Goods and Resolving the Paradox of Political Participation», la Dra. Carole J. Uhlaner nos propondrá una 
designed to generate and/or strengthen public goods. To this end, she clarifies the distinction between a relational good and a public good, thus precluding the confusion caused by this traditional entanglement, and analyses the subjective and objective dimensions characteristic of a relational good. Finally, based on surveys and field work, Uhlaner introduces us to the political reality of relational goods, in the way they demonstrate multiple and strong connections between people, to make sense of the democratic participation of civil society. First, she proposes that this paradox is based on a misinterpretation of the individual, as merely selfinterested, since collective action has more meaning and is more successful when it involves people who also value their relationships with others. She then demonstrates that such connections have the capacity to spread and generate relational processes with people who, although unknown to each other, share a common identity that links them in some way.

In the third article, "The commons from a critical social systems perspective", Dr. Wolfgang Hofkirchner raises the possibility of reflecting on common goods from a systemic and at the same time critical point of view; that is, common goods can be described in terms of systems and subsystems, although such a claim implies that its underlying normative

explicación plausible al desconcertante hecho de la participación democrática de la sociedad civil desde el punto de vista de los bienes relacionales; es decir, por qué las personas supuestamente egoístas son capaces de participar en procesos políticos cuyo objetivo es generar y/o potenciar bienes públicos. Para ello, la autora nos aclarará qué distingue un bien relacional de un bien público, evitando de ese modo la confusión que produce su tradicional entrelazamiento, así como en qué consisten la dimensión subjetiva y objetiva que caracteriza un bien relacional. Finalmente, apoyándose en encuestas y trabajos de campo, Uhlaner nos acercará a la realidad política de los bienes relacionales, en tanto que demostración de múltiples y fuertes conexiones existentes entre los seres humanos, para dotar de sentido la participación democrática de la sociedad civil. Por un lado, nos propondrá que tal paradoja subyace de una errónea interpretación del ser humano, en tanto que ser meramente autointeresado, puesto que la acción colectiva tiene más sentido y es más fructífera cuando se da en aquellas personas que también valoran sus relaciones con los demás.Y, por otro lado, nos enseñará que tales conexiones tienen la capacidad de extenderse y generar procesos relacionales con personas que, si bien son desconocidas, guardan una identidad común que las relaciona de algún modo. 
dimension must also be taken into account. The author puts forward a definition of common goods from a systemic perspective, in terms of the systemic effect of synergies that occur in social systems, and a normative perspective, in that such a claim requires additional critical reflection to avoid the processes of domination and exclusion that make the common a prisoner of the private.

In the fourth article, "Reconstruction of contractual justice from relational justice”, Dr. Rocía Caro-Gándara proposes a critical review of the contractual phenomenon from the perspective of relational law, since the process of transformation throughout the twentieth century now means that the binding force of contracts can no longer be focused on the parties' autonomy of will. To do this, the author shows how the current depletion of the paradigm of autonomy of will has led to different contextualist or relationalist proposals that redefine a contract model in the context of a new paradigm of relational justice. She then clarifies this emerging relational approach to justice, specifying its source of inspiration, relational sociology, and its traits, reciprocity, institutionality and sociality, as well as its potential for twenty-first century plural society. Based on all of the above, Caro-Gándara then presents her proposal for a general theory of

En el tercer artículo, titulado «The commons from a critical social systems perspective», el Dr. Wolfgang Hofkirchner nos planteará la posibilidad de abordar la reflexión sobre los bienes comunes desde un punto de vista sistémico y crítico al mismo tiempo; es decir, que los bienes comunes se pueden describir en términos de sistemas y subsistemas, pero que tal pretensión implica tener que preocuparse por dimensión normativa que le subyace. En este sentido, el autor nos propondrá una definición de los bienes comunes desde una perspectiva sistémica, en tanto que efecto sistémico de las sinergias que se producen en los sistemas sociales; y normativa, en tanto que tal pretensión requiere de una reflexión crítica complementaria que evite los procesos de dominación y exclusión que convierten lo común en prisionero de lo privado.

En el cuarto artículo, «Reconstrucción de la justicia contractual desde la justicia relacional», la Dra. Rocío Caro Gándara nos propondrá una revisión crítica del fenómeno contractual desde punto de vista del derecho relacional, puesto que el proceso de transformación que ha sufrido a lo largo del siglo xx impide actualmente seguir centrando la fuerza obligatoria de los contratos en la autonomía de la voluntad de las partes. Para ello, la autora nos mostrará cómo en el actual agotamiento del paradigma de la autonomía, la 
contractual justice in the context of a relational justice; that is, the need to adopt a relational approach to the contract - understood as a legal relationship - whose criterion of justice is expressed in the reciprocal activity of the parties and maintained over time by legal institutions.

Finally, in the fifth article, entitled "Relational Justice as virtuous circle" Dr. Antonio Márquez-Prieto also refers to the idea of relational justice to propose an interdisciplinary relational approach based on both Pierpaolo Donati's sociological proposal and on the economic notion of reciprocity developed by Luigino Bruni. In this line, and following Donati's relational sociology, the author shows justice as an emerging effect of the reciprocal link; in other words, as a result of interpersonal relationships sustained on the sphere of institutionality, the generation of mutual links and dependencies, and reciprocity, the relation between values and motivations or objectives. Márquez-Prieto also proposes strengthening the reciprocal link through Bruni's proposal for economic reciprocity, thus permitting the necessary continuous and dynamic game among the subjects of the relationship that the relational justice approach defended here allows. Márquez-Prieto concludes with his idea of relational justice as a virtuous circle, in that the various elements of the relationship - providing they are

voluntad ha producido diferentes propuestas contextualistas o relacionistas, que redefinen un modelo de contrato en el contexto de un nuevo paradigma de justicia relacional. Posteriormente, se centrará en tratar de clarificar este emergente enfoque relacional de justicia, concretando tanto la fuente de la que bebe -la sociología relacional-, como su personalidad -reciprocidad, institucionalidad y socialidad- y su potencialidad para la sociedad plural del siglo xxi. Finalmente, sustentándose sobre todo el bagaje anteriormente expuesto, Caro Gándara nos presentará su propuesta de una teoría general de la justicia contractual en el marco de una justicia relacional; es decir, en la necesidad de adoptar un enfoque relacional de contrato -entendido como una relación jurídica- cuyo criterio de justicia se encuentre expresado en la propia actividad recíproca de las partes y mantenida en el tiempo por la institucionalidad jurídica.

Finalmente, en el quinto artículo, titulado «Justicia relacional como círculo virtuoso», el Dr.Antonio Márquez Prieto nos introducirá de nuevo en la idea de justicia relacional para proponer un enfoque relacional interdisciplinar basado tanto en la propuesta sociológica de Pierpaolo Donati como en la noción económica de reciprocidad desarrollada por Luigino Bruni. En este sentido, y siguiendo la sociología relacional de Donati, el autor nos mostrará 
oriented towards justice - feed back to each other and thus avoid distortion, among other things.

Together, these five articles contribute an enlightening and enriching proposal on relational goods, exploring in the current context both their meaning and development and their application and implementation in different areas of human activity, such as political, economic and legal/ legislative activity.Also of note in all these articles is the value they attribute to the relational dimension of the individual and the goods s/he produces. Relational goods, as an emerging effect of the reciprocal relations among free subjects, are a cornerstone of civil society, positively affecting both its robustness and its enrichment and durability. Producing these goods is a new frontier, as they must not be confused with certain traditional goods of the past. These are goods that become truly possible and necessary in the context of a highly differentiated and complex society and as such represent a challenge for civil society in the twenty-first century.

la justicia como efecto emergente del vínculo recíproco; es decir, como fruto de aquellas relaciones interpersonales sustentadas sobre el ámbito de la institucionalidad - generación de vínculos y dependencias mutuas- y de la reciprocidad - relación entre valores y motivaciones u objetivos-. Por otro lado, Márquez Prieto nos propondrá potenciar el vínculo recíproco a través la propuesta económica de reciprocidad desarrollada por Bruni, un reforzamiento que permita de ese modo que el necesario juego continuo y dinámico entre los sujetos de la relación -que permite un enfoque de justicia relacional como el aquí defendido- acontezca. Finalmente, Márquez Prieto nos aporta su idea de justicia relacional como ć́rculo virtuoso, en tanto que los distintos elementos de la relación -en la medida que se orientan hacia la justicia - se retroalimentan entre sí evitando, entre otras cosas, desvirtuarse.

En su conjunto, estos cinco artículos aportan una propuesta clarificadora y enriquecedora sobre los bienes relacionales, ahondando en la actualidad tanto en su sentido y desarrollo como en su aplicación e implementación en diferentes ámbitos de actividad humana, tales como el político, el económico y el jurídico/legislativo. Además, destaca el valor que todos ellos atribuyen a la dimensión relacional del ser humano y los bienes que produce. Los bienes relacionales, en tanto que efecto emergente de las relaciones recíprocas entre sujetos libres, constituye un sostén fundamental de la sociedad civil, 


\section{REFERENCES}

Donati, P. (1993): "Pensamiento sociológico y cambio social: hacia una teoría relacional", 63, Reis. Revista Española de Investigaciones Sociológicas, pp. 29-52.

- (2000): La cittadinanza societaria, Roma-Bari, Laterza.

- (2013): Sociologia relazionale. Como cambia la società, Brescia. Editrice La Scuola.

Donati, P. and R. Solci (2011): I beni relazionale. Che cosa sono e quali effetti producono, Torino, Bollati Boringhieri.

Nussbaum, M. C. (1986): The Fragility of Goodness. Luck and Ethics in Greek Tragedy and Philosophy, Cambridge, Cambridge University Press.

incidiendo positivamente tanto en su robustez como en su enriquecimiento y perdurabilidad. La producción de estos bienes es una nueva frontera, puesto que no pueden ser confundidos con ciertos bienes tradicionales del pasado. Se trata de bienes que se convierten en posibles y necesarios propiamente en el contexto de una sociedad altamente diferenciada y compleja. Por esta razón, son un desafío para la sociedad civil en el siglo xxI.

\section{BIBLIOGRAFÍA}

Donatr, P. (1993): «Pensamiento sociológico y cambio social: hacia una teoría relacional», 63, Reis. Revista Española de Investigaciones Sociológicas, pp. 29-52.

- (2000): La cittadinanza societaria, Roma-Bari, Laterza.

- (2013): Sociologia relazionale. Como cambia la società, Brescia, Editrice La Scuola.

Donati, P. y R. Solci (2011): I beni relazionale. Che cosa sono e quali effetti producono, Torino, Bollati Boringhieri.

Nussbaum, M. C. (1986): The Fragility of Goodness. Luck and Ethics in Greek Tragedy and Philosophy, Cambridge, Cambridge University Press. 